\title{
Sweet Orange Juice : Blood Glucose Level After Having Anaerobic Activity
}

\author{
$1^{\text {st }}$ Indra Himawan Susanto \\ Sports Science \\ Universitas Negeri Surabaya \\ Surabaya, Indonesia \\ indrasusanto@unesa.ac.id
}

\author{
$2^{\text {nd }}$ Ananda Perwira Bakti \\ Sports Science \\ Universitas Negeri Surabaya \\ Surabaya, Indonesia \\ anandabakti@unesa.ac.id
}

\author{
$3^{\text {rd }}$ Yetty Septiani Mustar \\ Sports Science \\ Universitas Negeri Surabaya \\ Surabaya, Indonesia \\ yettymustar@unesa.ac.id
}

\begin{abstract}
The influence of blood glucose during exercise is a factor that affects the performance of the athlete. Blood glucose levels can be affected by things like activity or exercise, food and stress. If blood glucose levels decline, the function of brain cells is disrupted because nerve cells do not store carbohydrates as a result will have an impact on the decrease of athlete performance. Providing a sports drink with a 6-8\% carbohydrate can help improve the performance of the athlete. Giving sweet orange juice is a fruit that contains liquid, electrolytes, and carbohydrates can be used to replace lost fluids. The purpose of this study is to know the effect of the use of sweet orange juice to blood glucose. The research method used is laboratory experimental research, with research design used is pre - posttest group design. Sampling was conducted as many as 20 Students of Sports Science who were divided by control group and treatment group, men, age 20-23 years, healthy, and did not take supplements during the study. The result of this research is that there is a significant difference between pre and post in control group and treatment group that is control group $\mathbf{P}=$ 0,016 while treatment group $P=0,001$. The conclusion that can be drawn from this research is that the provision of sweet orange affects glucose levels after anaerobic activity.
\end{abstract} activity

Keywords- blood glucose, sweet orange juice, anaerobic

\section{INTRODUCTION}

Exercise can decrease blood glucose levels through increased muscle glucose intake, receptor sensitivity, and glucose transport. Exercise improves glucose transport through muscle contraction. Muscle contraction leads to an increase in the need for glucose in the muscles through the mechanism of insulin, signaling that GLUT4 switches the cell surface to bring glucose (Wulandari, 2013).

The availability of blood glucose during exercise is a factor that affects the performance of the athlete. Blood glucose levels can be affected by things like activity or exercise, food, and stress. When blood glucose levels decline, brain cell function is impaired because nerve cells do not store carbohydrates, as a result, will have an impact on decreasing athlete performance [5].

Muscle contractions always require ATP as energy, so rapid metabolism of energy in cells is required to produce
ATP. The greater the muscle contraction the greater the amount of ATP required. One of the dominant metabolic systems of energy during high-intensity physical exercise is the anaerobic glycolysis system. Anaerobic glycolysis systems have characteristics such as causing the formation of lactic acid, requiring no oxygen, and only using glucose or muscle glycogen as an energy source [4].

Liquids and minerals lost through sweat during exercise should be replaced either during exercise or afterward. There have been many sports drinks specially designed to replace fluids, minerals, and glucose during and after exercise [7].

Provision of beverages containing carbohydrates can help the body to prevent dehydration, maintaining blood glucose concentration and glycogen storage [1]. Providing a sports drink with a 6-8\% carbohydrate can help improve the performance of the athlete. Giving sweet orange juice is a fruit that contains liquid, electrolytes, and carbohydrates that can be used to replace lost fluids.

An Orange consist of water (86-92\%), sugar (5-8\%), pectin $(1-2 \%)$, glycosides $(0.1-1.5 \%)$, pentose $(0.8-1.2 \% \%)$, citric acid $(0.4-1.5 \%)$, fiber $(0.6-0.9 \%)$, protein $(0.6-0.8 \%)$, fat $(0.2-0.5 \%)$, minerals $(0,5-0,9 \%)$ and essential oil $(0,2-0,5 \%)$ (Siddiqi, 2005). An Orange and orange juice have many benefits because they contain potassium, calcium, folate, thiamin, niacin, vitamin B6, phosphorus, magnesium and copper

During exercise or physical exercise, many bodies lose fluids that lead to dehydration. Disease loss of $1-2 \%$ of body weight, evidence indicating that dehydration levels can significantly interfere with endurance and skill handling. Grapefruit juice can be used more as a substitute for fluids and electrolytes in preparation for, during and after exercise and competition (Baros, 2011). This study aims to determine the effect of sweet orange juice on blood glucose after anaerobic activity.

\section{MATERIALS AND METHODS}

\section{A. Subject}

Twenty man volunteers by using purposive random sampling who were all healthy, man between the ages $20-25$ 
years, have normal body mass index. The control group was 10 people and the treatment group was 10 people. The criteria for population harvesting are as follows: 1) sample of male and female of 20 - 23 years old. 2) A sample is a student of FIK UNESA 3) sample not taking the supplement during research. 4) No smoking sample. 5) Able-bodied sample.

\section{B. Instrument and Procedure}

The process of conducting the study is the subjects retrieved preliminary data for glucose levels, then subjects warm up and stretch for 10 minutes before performing tests to avoid unwanted injuries. The treatment is an anaerobic activity that runs $200 \mathrm{~m}$. Before the anaerobic activity of the students is taken preliminary data (Pre-test) in this case is GDA (Random Blood Sugar), then taken again after anaerobic activity for the final data (Post-test). After anaerobic activity, the sample of students in the control group was given $250 \mathrm{ml}$ of drinking water, while in the treatment group was given a drink of sweet orange juice as much as $250 \mathrm{ml}$.

\section{Statistical and analysis}

Descriptive statistics were determined for each variable recorded. Data are presented as mean \pm SD. Normality test to measure whether data obtained has a normal distribution so it can be used in parametric statistics (inferential statistics). Paired t-test and independent t-test was applied for Statistical evaluation of the data generated using SPSS (Statistical package for Social Studies) Version 19.0 Software.

\section{RESULT AND DISCUSSION}

The result of the research is the measurement data obtained from the research cover the whole variable data that is independent variable, dependent variable, and control variable.

The following descriptive analysis of weight, height, GDA pre-test and post-test GDA data were presented in the table below

The average of the characteristics research according weight and height. Body weight in the control group obtained mean of $66,20 \pm 9,841$; body weight in the treatment group obtained mean of $60,70 \pm 9,476$. The height in the control group was $172,00 \pm 8,692$; height in the treatment group obtained mean of 169,30 $\pm 5,697$. (Table 1).

TABLE 1. CHARACTERISTIC OF THE SUBJECT

\begin{tabular}{lll}
\hline Characteristic of the subject & Mean & SD ( \pm ) \\
\hline weight control & 66,20 & 9,841 \\
weight treatment & 60,70 & 9,476 \\
height control & 172,00 & 8,692 \\
height treatment & 169,30 & 5,697 \\
\hline
\end{tabular}

Pre-control sugar levels in the control group were $91.40 \pm$ 4.624; the pre-treatment of sugar in the treatment group was obtained $84.40 \pm 7,849$ average. Sugar content of post in control group was obtained mean of 99,00 $\pm 8,994$; post-feed sugar content in the treatment group was $106,90 \pm 10,016$. (Table 2)

TABLE 2. AVERAGE OF BLOOD GLUCOSA LEVEL CONTROL GROUP AND TREATMENT GROUP

\begin{tabular}{lcl}
\hline Group & Mean & SD ( \pm$)$ \\
\hline Pre control & 66,20 & 9,841 \\
Pre treatment & 60,70 & 9,476 \\
Post control & 172,00 & 8,692 \\
Post treatment & 169,30 & 5,697 \\
\hline
\end{tabular}

Normality test data are analyzed using the Shapiro-Wilk Test. (Table 3) Based on table 2 obtained pvalue $>0.05$, it means that all of data for glukosa level pre and post are normally distributed.

TABLE 3. NORMALITY TEST

\begin{tabular}{ll}
\hline Group & $\begin{array}{l}\text { Glukosa } \\
(\mathrm{mg} / \mathrm{dl})\end{array}$ \\
\hline Pre control & 0,510 \\
Post control & 0,609 \\
Pre treatment & 0,818 \\
Post treatment & 0,510 \\
\hline
\end{tabular}

The result of this research is there is significant difference between pre and post in control group and treatment group that is control group $\mathrm{P}=0,016$ while treatment group $\mathrm{P}=$ 0,001. (Table 4)

TABLE 4. STATISTICAL RESULTS OF INDEPENDENT T-TEST:

\begin{tabular}{ll}
\hline Blood Glucosa level & pvalue \\
\hline Pre & 0,016 \\
Post & 0,001 \\
\hline
\end{tabular}

This research is a laboratory experimental research, with research design used is pre - posttest group design. Sampling was conducted as many as 20 Students of Faculty of Sport Science who were divided by control group and treatment group, men, age 20-23 years, healthy, and did not take supplements during the study. Both groups were given $200 \mathrm{~m}$ sprint sprints. After the $200 \mathrm{~m}$ sprint, the control group was given $250 \mathrm{ml}$ of mineral water while the treatment group was given $250 \mathrm{ml}$ of sweet orange juice. In this study examined blood glucose levels before and after sprint activity $200 \mathrm{~m}$.

The result of the mean of pre sugar level in the control group was $91,40 \pm 4,624$; post-control sugar content in the control group was found to be $99,00 \pm 8,994$. Paired t-test results obtained significant results between the pre control group and post control group where $p=0.016<0.05$. From the above results in the control group given $250 \mathrm{ml}$ mineral water 
drink showed increased glucose levels before and after sprint $200 \mathrm{~m}$ run. During physical exercise there will be increased use of muscle glycogen and blood glucose according to the severity of physical activity. In the control group given is mineral water, drinks that contain no carbohydrates or glucose that is only able to maintain body hydration.

The results of this study also show the average increase in the difference between pre and post in both groups. The average increase in the difference in the treatment group was higher than that of the control group, which resulted in the provision of a source of energy for sports activities faster and better.

The mean of pre-sugar content in the treatment group was $84.40 \pm 7.849$; post-feed sugar content in the treatment group was $106,90 \pm 10,016$. Paired t-test results showed significant results between the pre-treatment group and the post-treatment group where $\mathrm{p}=0.001<0.05$. From the above results in the treatment group given $250 \mathrm{ml}$ sweet orange juice drink showed a significant increase in glucose levels before and after sprint $200 \mathrm{~m}$. The content of carbohydrates or glucose in pacitan sweet orange juice able to keep blood glucose levels so as not below $80 \mathrm{mg} / \mathrm{dl}$. The main purpose of consuming beverages containing carbohydrate after exercise is to maintain the hydration of the body, and able to provide energy source in blood and maintain the glycogen reserves in muscle (Miharja, 2004).

\section{CONCLUSION}

Based on the results of the research, it can be concluded that the administration of pacitan sweet orange juice affect blood glucose levels after anaerobic activity.

\section{REFERENCE}

[1] Alfiana Lana. 2012. "The Influence of Coconut Water Provision to Fitness of Football Athlete". Research Articles. Study In Nutrition Sciences Program Faculty of Medicine Universitas Diponegoro. Semarang

[2] Cabrera M- CG, Domenech E, Romagnoli M, et al. "Oral administration of vitamin $\mathrm{C}$ decreases muscle mitochondrial biogenesis and hampers training-induced adaptations in endurance," The American Journal of Clinical Nutrition. 2008; 87: 142-149

[3] Evans, W. J. (2000), "Vitamin E, vitamin C, and exercise," Am J Clin Nutr, 72, 647S - 652S.

[4] Fox EL, Browers RW, and Foss ML, 1998, "The Physiological Basic Of Exercise and Sport Fifth Edition," USA : Wim C. Brown Publisher.

[5] Heater HF, Willam MH. 2007, "Nutrition for health, fitness, and sport," 8th edition, New York: Mc Graw-Hiil Companies, inc;

[6] Heater HF,Lisa AB, Alan EM, "Practical application in sports nutrition," 3rd ed. United States of America: Jones and Bartlett Publisher; 2006.

[7] Kushartanti Wara. 2007. "The Influences Of Sports Drink After Exercising On Glucose And Blood Pressure Patients Diabetes Mellitus And Hypertension". Yogyakarta.

[8] McArdle WD, Katch FI, and Katch VL, 2010, "Exercise Physiology : Energy, Nutrition, and Human Performance," 7th Edition. Lippincott : Philadelphia.

[9] Purwanto B, 2014, "Working Mechanism Curcumin In Preventing Muscle Damage Mice Frame Which Perform Short Time Eccentric Activity," Disertasi. Fakultas Kedokteran Universitas Airlangga.
[10] Siddiqi NA, 2005, "Debittering of sweet orange by resin. M. Tech. Thesis, Collegeof Food Technology. Marathwada Krishi Vidyapeeth, Parbhani, Maharashtra, India.

[11] Surangi H.T. and H.P. Vasantha R., 2013, "Flavonoid Bioavailability and Attempts for Bioavailability Enhancement," Nutriens 5 : 3367-3387.

[12] Sutopo, 2011, "Pacitan Oranges Cultivation Guide," Available from: http://kpricitrus.wordpress.com/2011/02/13/penanganan-panen-danpaska panenjeruk/. Accessed in 10 March 2017

[13] Yunus, Moch. 2001, "Effect of Antioxidant Vitamin C Against MDA Wistar Erythrocyte Rats Due to Anaerobic Exercise," Journal of Physical Education, (1): 9-16. 